VOL. 1 NO. 1 JUNI 2017

\title{
Pengembangan Media Pembelajaran Sistem Pencernaan Manusia Untuk Kelas 8 Smp Dengan Fitur Augmented Reality Berbasis Android (Studi Kasus : Smpn 7 Depok)
}

\author{
Juannita ${ }^{1}$, Bambang Prasetya Adhi ${ }^{2}$ \\ Pendidikan Teknik Informatika dan Komputer, Teknik Elektro, FT - UNJ \\ 1 juannita93@ymail.com, ${ }^{2}$ bambangpadhi@unj.ac.id
}

\begin{abstract}
Abstrak
Kurangnya media pembelajaran yang memudahkan dalam mempelajari materi sistem pencernaan manusia menjadi kendala tersendiri bagi guru dan murid sehingga dilakukan penelitian yang bertujuan untuk mengembangkan dan mengetahui keefektifan media pembelajaran sistem pencernaan manusia untuk kelas 8 SMP dengan fitur Augmented Reality berbasis Android dengan mengambil studi kasus di SMPN 7 Depok. Penelitian ini menggunakan metode Research and Development $(R \& D)$ dengan model pengembangan ADDIE yang terdiri dari lima tahapan yaitu Analisis (Analyze), Perancangan (Design), Pengembangan (Development), Penerapan (Implementation), dan Evaluasi (Evaluation). Instrumen yang digunakan dalam menguji kelayakan dan keefektifan media pembelajaran adalah angket dan soal tes. Media pembelajaran diuji kelayakannya oleh ahli materi dan ahli media dengan hasil media pembelajaran layak untuk digunakan oleh siswa. Untuk menguji keefektifan media pembelajaran dilakukan melalui pretest dan posttest serta angket tanggapan siswa setelah menggunakan media pembelajaran, dengan hasil tes terdapat peningkatan hasil belajar signifikan setelah menggunakan media pembelajaran serta hasil angket yang mendapatkan total presentase 88,56\% dengan keterangan sangat baik. Berdasarkan hasil evaluasi, media pembelajaran layak dan efektif untuk digunakan dalam pembelajaran materi sistem pencernaan manusia untuk kelas 8 SMP.
\end{abstract}

Kata kunci : Media Pembelajaran, Sistem Pencernaan Manusia untuk Kelas 8 SMP, Augmented Reality, Android.

\section{Pendahuluan}

Sistem pencernaan manusia adalah sistem yang terdiri dari organ-organ pencernaan yang berfungsi untuk mencerna makanan pada tubuh manusia diantaranya adalah mulut, esofagus, lambung, pankreas, hati, empedu, usus halus, usus besar, dan anus.

Sistem pencernaan manusia merupakan materi pembelajaran pada kurikulum 2013 yang penting untuk dipelajari , materi sistem pencernaan manusia didapat saat kelas 8 SMP pada mata pelajaran IPA di semester ganjil. Umumnya, untuk mempelajari sistem pencernaan manusia, guru hanya menjelaskan dengan bantuan media belajar menggunakan buku cetak, poster ataupun menggunakan alat peraga. Namun, mempelajari sistem pencernaan manusia memiliki kendala tersendiri, dikarenakan materi yang dianggap kurang menarik bagi anak-anak. Buku cetak dan poster yang masih kurang efektif karena siswa masih merasa sulit membayangkan bagaimana bentuk dan letak organ-organ pencernaan pada tubuh manusia, sedangkan patung peraga yang mempermudah siswa dalam memahami organ-organ pencernaan sering rusak karena sering dimainkan oleh siswa dan harganya yang relatif mahal.

Dengan pesatnya kemajuan teknologi, teknologi komputer dapat digunakan disegala aspek kehidupan manusia dari yang sederhana hingga pekerjaan yang rumit sekalipun. Salah satunya adalah teknologi Augmented Reality.

Augmented Reality (AR) atau dalam bahasa Indonesia disebut realitas tertambah adalah teknologi yang menggabungkan benda maya dua dimensi ataupun tiga dimensi ke dalam sebuah lingkungan nyata, lalu memproyeksikan benda-benda maya tersebut dalam waktu nyata. Benda-benda maya berfungsi menampilkan informasi yang tidak dapat diterima oleh manusia secara langsung. Hal ini membuat Augmented Reality berguna sebagai alat untuk membantu persepsi dan interaksi penggunanya dengan dunia nyata. Informasi yang ditampilkan oleh benda maya membantu pengguna melaksanakan kegiatan-kegiatan dalam dunia nyata. Menurut Ronald T. Azuma (1997:1), ada tiga prinsip dari Augmented Reality. Yang pertama yaitu Augmented Reality merupakan penggabungan dunia nyata dan virtual, yang kedua berjalan secara interaktif dalam waktu nyata (realtime), dan terdapat integrasi antar 
benda dalam tiga dimensi, yaitu benda maya terintegrasi dalam dunia nyata.

Fitur Augmented Reality dapat dimanfaatkan dalam menampilkan objek 3D organ-organ sistem pencernaan manusia serta video cara kerja sistem pencernaan pada aplikasi media pembelajaran sistem pencernaan manusia sehingga dapat memperjelas materi sistem pencernaan manusia.

Saat ini, perkembangan teknologi Mobile Android sudah sangat berkembang. Jumlah pengguna Mobile Android di Indonesia mengalami pertumbuhan yang sangat pesat, dengan peningkatan sebesar 150\% dari tahun 2014 ke 2015 dan diperkirakan akan terus mengalami peningkatan setiap tahunnya (inet.detik.com,2015). Oleh karena itu, perangkat Mobile Android yang mana memiliki banyak pengguna di Indonesia memiliki potensi yang besar untuk dijadikan perangkat untuk menjalankan aplikasi media pembelajaran menggunakan teknologi Augmented Reality. Berdasarkan hasil observasi awal di SMPN 7 Depok 70,71\% dari total murid kelas 8 dan kedua guru IPA kelas 8 menggunakan smartphone Android sehingga SMPN 7 Depok merupakan sekolah yang tepat untuk menguji coba aplikasi media pembelajaran sistem pencernaan manusia dengan fitur Augmented Reality berbasis Android.

Proses belajar mengajar mata pelajaran IPA dengan materi sistem pencernaan manusia di SMPN 7 Depok hanya mengandalkan buku cetak tanpa bantuan media pembelajaran lain sehingga sebagian besar siswa masih merasa kurang paham dan kurang tertarik oleh materi sistem pencernaan manusia serta guru yang kesulitan dalam mengajarkan materi sistem pencernaan manusia hanya dengan mengandalkan buku cetak saja. Oleh karena itu dibuatlah suatu aplikasi dengan fitur Augmented Reality yang bertujuan untuk memudahkan dalam mempelajari sistem pencernaan manusia pada smartphone Android.

Aplikasi ini memiliki beberapa keunggulan, tidak hanya menampilkan objek 3D organ-organ sistem pencernaan manusia dan video cara kerja sistem pencernaan dengan fitur Augmented Reality tetapi juga menampilkan informasi masing-masing organ pencernaan,, penjelasan enzim-enzim pada pencernaan, dan penjelasan mengenai macam-macam gangguan pada pencernaan, serta Marker untuk menampilkan objek 3D dicetak pada media baju sehingga siswa dapat langsung mengetahui bentuk dan letak masing-masing organ pada tubuh manusia.

Aplikasi ini diharapkan dapat menjadikan materi sistem pencernaan manusia menjadi lebih mudah dimengerti dan lebih menyenangkan untuk dipelajari serta memudahkan guru untuk mengajarkan materi sistem pencernaan manusia.

Berdasarkan latar belakang di atas, dibuatlah skripsi yang berjudul “Pengembangan Media Pembelajaran Sistem Pencernaan Manusia untuk Kelas 8 SMP dengan Fitur Augmented Reality

\section{Berbasis Android (Studi Kasus : SMPN 7 Depok)".}

\section{Dasar Teori}

Pada bagian ini diuraikan landasan teoritis yang berhubungan dengan penelitianyang dilakukan.

\subsection{Media Pembelajaran}

Gagne Briggs (dalam Arsyad,2001:4) secara implisit mengatakan bahwa media pembelajaran meliputi alat yang secara fisik digunakan untuk menyampaikan isi materi pengajaran, yang terdiri antara lain buku, tape recorder, kaset, video camera, film, slide (gambar bingkai), foto, gambar, grafik, televisi, dan komputer.

Sedangkan menurut Sadiman (2008:7), diacu dalam Arif Rahman (2010:15) menjelaskan media pembelajaran adalah segala sesuatu yang dapat digunakan untuk menyalurkan pesan dari pengirim ke penerima pesan.

Dari berbagai pendapat tersebut,dapat simpulkan bahwa media pembelajaran adalah perantara yang digunakan untuk menyalurkan informasi dari isi materi pengajaran dari pengirim pesan (guru) ke penerima pesan(siswa).

\subsection{Sistem Pencernaan Manusia untuk Kelas 8 SMP}

Materi sistem pencernaan manusia utuk keas 8 SMP termasuk pada mata pelajaran IPA semester ganjil kurikulum 2013. Berikut adalah tabel 2.1 yang berisi kompetensi dasar serta materi pembelajaran sistem pencernaan manusia :

Tabel 2.1 Kompetensi Dasar dan Materi Pembelajaran

\begin{tabular}{|ll|l|}
\hline Kompetensi Dasar & Materi Pembelajaran \\
\hline 3.5 & $\begin{array}{l}\text { Menganalisis } \\
\text { sistem pencernaan } \\
\text { pada manusia dan } \\
\text { memahami }\end{array}$ & $\begin{array}{l}\text { Sistem Pencernaan } \\
\text { pada manusia }\end{array}$ \\
$\begin{array}{l}\text { 1. Zat makanan } \\
\text { gangguan yang } \\
\text { berhubungan } \\
\text { dengan sistem } \\
\text { pencernaan, serta } \\
\text { upaya menjaga } \\
\text { kesehatan sistem } \\
\text { pencernaan. }\end{array}$ & $\begin{array}{l}\text { 3. Organ pencernaan } \\
\text { 4. Enzim pencernaan } \\
\text { berhubungan } \\
\text { dengan sistem } \\
\text { pencernaan }\end{array}$ \\
& \\
\hline
\end{tabular}

\subsection{Augmented Reality}

Augmented Reality (AR) atau dalam bahasa Indonesia disebut realitas tertambah adalah teknologi yang menggabungkan benda maya dua dimensi dan atau pun tiga dimensi ke dalam sebuah lingkungan nyata lalu memproyeksikan benda-benda maya tersebut dalam waktu nyata (real-time). Benda-benda 
maya berfungsi menampilkan informasi yang tidak dapat diterima oleh manusia secara langsung. Hal ini membuat Augmented Reality berguna sebagai alat untuk membantu persepsi dan interaksi penggunanya dengan dunia nyata. Informasi yang ditampilkan oleh benda maya membantu pengguna melaksanakan kegiatan-kegiatan dalam dunia nyata . ada tiga prinsip dari Augmented Reality, yang pertama yaitu AR merupakan penggabungan dunia nyata dan virtual, yang kedua berjalan secara interaktif dalam waktu nyata (real-time), dan yang ketiga terdapat integrasi antar benda dalam tiga dimensi, yaitu dalam benda maya terintegrasi dalam dunia nyata (Ronald T.Azuma,1997) .

\subsection{Android}

Menurut Nasruddin Safaat (2012:1), diacu dalam Septi Evrilla (2011) Android adalah sebuah sistem operasi pada handphone yang bersifat terbuka dan berbasis pada sistem operasi Linux. Android bisa digunakan oleh setiap orang yang ingin menggunakannya pada perangkat mereka.

Android menyediakan Platform terbuka bagi para pengembang untuk menciptakan aplikasi mereka sendiri yang akan digunakan untuk bermacam peranti bergerak. Awalnya, Google Inc. membeli Android Inc., pendatang baru yang membuat peranti lunak untuk ponsel. Kemudian untuk mengembangkan Android, dibentuklah Open Handset Alliance, konsorsium dari 34 perusahaan peranti keras, peranti lunak, dan telekomunikasi, termasuk Google, HTC, Intel, Motorola, Qualcomm, T- Mobile, dan Nvidia. Pada saat perilisan perdana Android, 5 November 2007, Android bersama Open Handset Allian ce menyatakan mendukung pengembangan standar terbuka pada perangkat seluler. Di lain pihak, Google merilis kode - kode Android di bawah lisensi Apache, sebuah lisensi perangkat lunak dan standar terbuka perangkat seluler.

\section{Metodologi}

Penelitian ini menggunakan metode Research and Development (R\&D) dengan memberi fokus pada aspek pengembangan. Hal ini sesuai dengan penelitian yang berusaha membuat dan mengembangkan sebuah produk media pembelajaran sistem pencernaan manusia untuk kelas 8 SMP yang dapat menunjang kegiatan pembelajaran dan mempermudah guru dalam mengajarkan materi.. ADDIE yang mencakup aspek Analyze (analisis), Design (perancangan), Development (pengembangan), Implementation (penerapan), dan Evaluation (Evaluasi).

Alasan digunakannya model pengembangan ADDIE, dikarenakan ADDIE memiliki keunggulan yaitu dilihat dari prosedur kerjanya yang sistematik yakni pada setiap langkah yang akan dilalui selalu mengacu pada langkah sebelumnya yang sudah diperbaiki sehingga diperoleh produk yang efektif.
Berikut bagan model pengembangan yang digunakan dalam penelitian dan pengembangan media pembelajaran sistem pencernaan manusia.

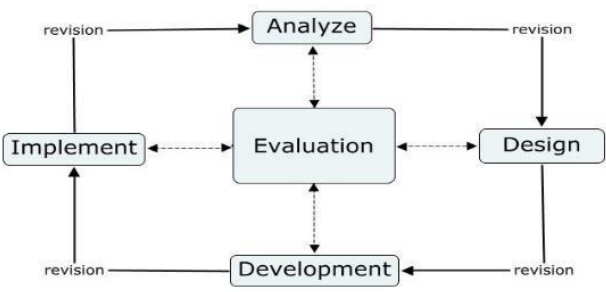

Gambar 3.1 Tahap Pengembangan ADDIE

\section{1. Tahap Perencanaan dan Pengumpulan Informasi}

Dalam mengembangkan media pembelajaran sistem pencernaan manusia untuk kelas 8 SMP dengan fitur Augmented Reality berbasis Android memerlukan penelitian pendahuluan yang berupa analisis kinerja dan analisis kebutuhan yang mana untuk mengetahui apakah permasalahan yang terjadi membutuhkan solusi berupa pengembangan media pembelajaran serta apa saja yang dibutuhkan dalam mengembangkan media pembelajaran tersebut. Dalam menganalisis kinerja dan kebutuhan, pada tahapan penelitian ini menggunakan metode observasi , wawancara dan tes.

\section{2. Tahap Perencanaan}

Aplikasi AR Digestive sebagai media pembelajaran sistem pencernaan manusia dengan fitur Augmented Reality berbasis Android menampilkan objek 3D organ-organ pencernaan manusia, video cara kerja sistem pencernaan, informasi masing-masing organ pencernaan, penjelasan enzim-enzim pada pencernaan, dan penjelasan mengenai macam-macam gangguan pada pencernaan. untuk mengetahui apakah media ini sudah memenuhi kriteria yaitu kevalidan, kepraktisan, dan kefektifan maka dilakukan beberapa evaluasi. Untuk mengetahui apakah media sudah valid atau belum maka dilakukan uji kelayakan untuk mengetahui apakah media ini ini layak untuk diuji cobakan kepada siswa maka diakukan evaluasi formatif atau uji kelayakan yang dilakukan oleh ahli media dan ahli materi, apabila belum dinyatakan layak maka harus direvisi. Untuk mengetahui kepraktisan media diketahui melalui aspek mudah digunakan dan fleksibilitas instruksional pada angket uji kelayakan kepada ahli dan uji efektivitas kepada siswa.Setelah dikatakan layak maka untuk mengetahui apakah media ini efektif dilakukan pretest dan posttest untuk mengetahui apakah terjadi peningkatan pemahaman siswa terhadap materi setelah menggunakan media dan angket tanggapan siswa yang dilakukan untuk mengetahui respon siswa terhadap media.

\section{3. Tahap Desain Produk}

Prosedur pengembangan aplikasi AR Digestive sebagai media pembelajaran organ-organ sistem 
pencernaan manusia mengikuti tahapan-tahapan pada model pengembangan ADDIE, Berikut adalah penjabaran dari kelima tahapan ADDIE yang disesuaikan dengan penelitian ini.

1. Analisis

Pada tahapan ini dilakukan analisis kinerja untuk mengetahui apakah permasalahan membutuhkan solusi berupa pengembangan media pembelajaran serta analisis kebutuhan untuk mengetahui apa saja kebutuhan yang dibutuhkan dalam mengembangkan media pembelajaran.

2. Perancangan

Pada tahapan ini dirancanglah RPP, struktur navigasi, tampilan halaman aplikasi serta alat evaluasi.

3. Pengembangan

Pada tahapan ini dilakukan pengembangan media pembelajaran serta evaluasi formatif yang dilakukan oleh ahli media dan ahli materi.

4. Penerapan

Pada tahapan ini setelah media pembelajaran dinyatakan layak oleh ahli media serta ahli materi maka media pembeajaran sudah siap diuji cobakan terhadap siswa. Uji coba dilakukan terhadap siswa kelas 8-2 di SMPN 7 Depok.

5. Evaluasi

Pada tahapan ini dilakukan evaluasi sumatif dengan menggunakan pretest dan posttest serta angket tanggapan siswa.

\section{Hasil dan Analisis}

\section{1. Hasil Penelitian}

Hasil pada penelitian ini adalah sebuah media pembelajaran sistem pencernaan manusia untuk kelas 8 SMP dengan fitur Augmented Reality berbasis Android yang dinamakan aplikasi AR Digestive. Berikut merupakan salah satu tampilan halaman pada aplikasi AR Digestive :

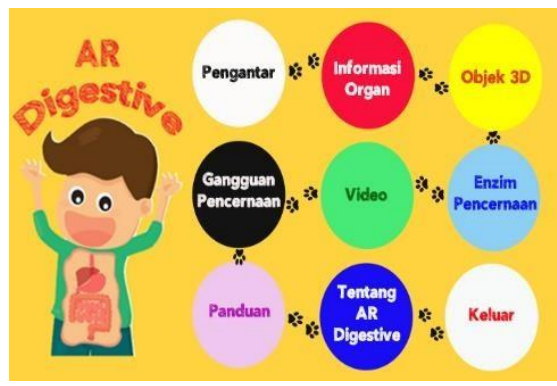

Gambar 4.1 Halaman Menu Utama

\section{1.1. Uji Kelayakan Oleh Ahli}

Aplikasi AR Digestive yang telah selesai dikembangkan diuji kelayakannya menggunakan angket dengan skala guttman oleh dua ahli materi dan dua ahli media dengan penilaian semua aspek terpenuhi dan mendapatkan hasil bahwa Aplikasi AR Digestive dinyatakan layak.

\section{1.2. Pretest dan Posttest}

Berdasarkan hasil dari pretest dan posttest menggunakan uji normalitas bahwa data berdistribusi normal, kemudian dengan uji $\mathrm{T}$ (paired sample t test) dengan hasil $\mathrm{T}_{\text {hitung }}=2,0$, maka $\mathrm{T}_{\text {hitung }}>\mathrm{T}_{\text {tabel }} 2,0>-$ 1,69. Sehingga $\mathrm{H}_{0}$ ditolak dan $\mathrm{H}_{1}$ diterima. Dan dapat diambil kesimpulan bahwa terdapat peningkatan yang signifkan pada hasil belajar siswa setelah menggunakan aplikasi AR Digestive.

\section{1.3. Hasil Angket Tanggapan Siswa}

Angket tanggapan siswa diisi oleh 32 siswa kelas 8-2 setelah menggunakan aplikasi AR Digestive, berdasarkan tanggapan siswa didapatkan hasil bahwa setiap aspek memiliki keterangan sangat baik dengan jumlah persentase $88,56 \%$.

\section{2. Pembahasan}

Pengembangan media pembelajaran sistem pencernaan untuk kelas 8 SMP dengan fitur Augmented Reality berbasis Android dikemas dalam bentuk apk yang siap diinstall dalam Smartphone dengan sistem operasi Android dengan persyaratan minimum yang telah ditentukan. Media pembelajaran ini dinamakan aplikasi AR Digestive yang berisi materi sistem pencernaan manusia yang meliputi materi organ pencernaan, enzim pencernaan, dan penyakit yang berhubungan dengan sistem pencernaan. Penelitian ini mengambil studi kasus di SMPN 7 Depok.

Aplikasi AR Digestive telah di uji kelayakannya oleh dua ahli media dan dua ahli materi dan dinyatakan layak untuk diuji cobakan terhadap siswa.Sedangkan berdasarkan uji kefektifan, untuk mengetahui apakah media membantu dan memudahkan siswa untuk belajar berdasarkan hasil angket tanggapan siswa nomor 13 dan 17 mendapatkan rata-rata presentase $90 \%$ dengan keterangan sangat baik, untuk mengetahui apakah media menarik minat siswa untuk belajar berdasarkan hasil angket tanggapan siswa butir nomor 11 dan 15 mendapatkan rata-rata presentase $87 \%$ dengan keterangan sangat baik, untuk mengetahui media dapat meningkatkan pemahaman siswa dapat dilihat berdasarkan hasil pretest dan posttest yang di uji menggunakan uji t paired sample dengan hasil $\mathrm{T}_{\text {hitung }}$ $>\mathrm{T}_{\text {tabel }} 2,0>-1,69$ dengan keterangan terjadi peningkatan signifikan terhadap hasil belajar, untuk mengetahui apakah media membuat siswa menjadi lebih aktif dapat dilihat pada hasil angket tanggapan siswa butir nomor 16 mendapatkan presentase $88 \%$ dengan keterangan sangat baik, untuk mengetahui apakah media dapat digunakan secara mandiri dan digunakan dimana saja oleh siswa dapat dilihat pada hasil angket tanggapan siswa dengan butir nomor 12 dan 14 dengan rata-rata presentase $88 \%$ dengan keterangan sangat baik, sedangkan apakah media dapat menggantikan pembelajaran sebelumnya dapat dilihat dari hasil uji kelayakan dan hasil uji keefektifan media. Karena media dikatakan layak dan 
efektif bagi siswa maka media dapat menggantikan media pembelajaran sebelumnya.

Dalam mengembangkan produk ini terdapat faktor pendukung dan faktor penghambat, faktor pendukung diantaranya: (1) Banyaknya siswa kelas 8 pengguna smartphone Android serta mudahnya penggunaan smartphone Android, (2) Kedua guru IPA kelas 8 menggunakan smartphone Android, (3) Tingginya antusiasme siswa dalam menggunakan media pembelajaran, (4) Pihak sekolah yang antusias dan mau memberikan masukan dalam mengembangkan aplikasi AR Digestive. Sedangkan faktor penghambatnya adalah: (1) Tidak semua siswa kelas 8 menggunakan smartphone Android dan (2) Kaos AR yang disediakan sebagai marker tidak mencukupi kebutuhan semua siswa sehingga harus dicetak di kertas juga.

Sebagai hasil produk pengembangan, aplikasi AR Digestive memiliki kelebihan dan kelemahan. Kelebihannya diantaranya: (1) Terdapat fitur Augmented Reality untuk menampilkan objek 3D organ pencernaan dan video cara kerja sistem pencernaan yang dapat meningkatkan pemahaman serta menarik minta siswa dalam mempelajari sistem pencernaan manusia, selain itu terdapat penjelasan informasi organ, enzim pencernaan, dan penyakit yang berhubungan dengan sistem pencernaan, (2) Aplikasi AR Digestive dapat digunakan dimana saja, (3) Penyampaian materi dikemas menarik dengan adanya gambar-gambar kartun dan musik latar untuk menarik minat siswa, (4) Aplikasi AR Digestive mudah untuk diinstall dan digunakan, dan (5) Dengan adanya aplikasi AR Digestive siswa dapat belajar secara mandiri.

Selain kelebihan diatas, kelemahan dari aplikasi aplikasi AR Digestive adalah: (1) Siswa harus menyediakan marker sendiri dengan cara mencetak gambar marker pada kaos ataupun kertas dan (2) Aplikasi AR Digestive hanya dapat dijalankan pada smartphone Android saja.

\section{Kesimpulan, Implikasi, dan Saran}

\section{1. Kesimpulan}

Berdasarkan hasi penelitian dan pembahasan yang telah dilakukan, maka dapat ditarik kesimpulan sebagai berikut :

1. Dalam mengembangkan media pembelajaran sistem pencernaan manusia untuk kelas 8 SMP dengan fitur Augmented Reality berbasis Android yang dinamakan aplikasi AR Digestive menggunakan model pengembangan ADDIE yang memiliki tahapan analisis (analyze) yang dibagi menjadi dua yaitu analisis kinerja dan analisis kebutuhan, tahapan perancangan (design), tahapan pengembangan (development), tahapan penerapan (Implementation), dan tahapan evaluasi (evaluation)
2. Aplikasi AR Digestive sudah layak untuk digunakan oleh siswa berdasarkan hasil angket dari ahli materi dan ahli media, serta dinyatakan efektif karena sudah memenuhi tujuan pengembangan dari aplikasi AR Digestive yaitu media membantu dan memudahkan siswa untuk belajar mendapatkan rata-rata presentase $90 \%$ dengan keterangan sangat baik, media menarik minat siswa untuk belajar mendapatkan rata-rata presentase $87 \%$ dengan keterangan sangat baik, media dapat meningkatkan pemahaman siswa dapat dilihat berdasarkan hasil pretest dan posttest yang di uji menggunakan uji t paired sample dengan hasil Thitung > Ttabel 2,0 > -1,69 dengan keterangan terjadi peningkatan signifikan terhadap hasil belajar, media membuat siswa menjadi lebih aktif mendapatkan presentase $88 \%$ dengan keterangan sangat baik, untuk mengetahui apakah media dapat digunakan secara mandiri dan digunakan dimana saja oleh siswa mendapatkan rata-rata presentase $88 \%$ dengan keterangan sangat baik, sedangkan apakah media dapat menggantikan pembelajaran sebelumnya dapat dilihat dari hasil uji kelayakan dan hasil uji keefektifan media. Karena media dikatakan layak dan efektif bagi siswa maka media dapat menggantikan media pembelajaran sebelumnya.

\section{2. Implikasi}

Berdasarkan pembahasan hasil penelitian dan kesimpulan yang diambil dalam penelitian ini, maka ada beberapa implikasi yang dapat dikemukakan sebagai berikut :

1. Penggunaan aplikasi AR Digestive dalam pembelajaran membuat siswa lebih aktif sehingga menarik minat siswa untuk mempelajari materi sistem pencernaan manusia.

2. Aplikasi AR Digestive dapat menarik minat siswa dalam mempelajari materi sistem pencernaan manusia ditambah dengan jelasnya penyampaian materi dari aplikasi AR Digestive dapat mempermudah siswa dalam memahami materi.

3. Aplikasi AR Digestive mempermudah siswa dalam memahami materi sistem pencernaan sehingga dapat meningkatkan hasil belajar siswa dibandingkan belajar dengan cara konvensional.

\section{3. Saran}

Berdasarkan hasil penelitian, pembahasan, dan kesimpulan, maka saran yang dapat diberikan pada penelitian ini adalah: 
1. Sesuai dengan hasil penelitian bahwa aplikasi AR Digestive layak dan efektif dalam pembelajaran sistem pencernaan manusia maka ada baiknya untuk diterapkan dalam proses belajar mengajar materi sistem pencernaan untuk kelas 8 di sekolah.

2. Diharapkan adanya pengembangan lebih lanjut terhadap aplikasi AR Digestive seperti penambahan fitur pengerjaan soal evaluasi materi dan dapat digunakan oleh semua jenis sistem operasi.

\section{Daftar Pustaka:}

Andhi Siswanto. (2012). Perancangan Alat Peraga 3D Mengenal Macam-Macam Binatang Berbasis Augmented Reality (AR) di TK ABBA 33

Arikunto, Suharsimi. (2002). Prosedur Penelitian Suatu Pendekatan Praktek. Jakarta : Rineka Cipta.

Arsyad, Azhar. (2013). Media Pembelajaran. Jakarta: Rajawalli Pers .

Azuma, Ronald T. (1997). A Survey of Augmented Reality, Hughes Research Laboratories, Malibu.

Cecep, K. \& Bambang, S. (2011). Media Pembelajaran : Manual dan Digital. Bogor: Penerbit Ghalia Indonesia.

Eka Legya Frannita. 2016. Pengembangan dan Analisis Media Pembelajaran Perakitan Komputer Berbasis Augmented Reality untuk Platform Android di SMK YPKK I Sleman. Yogyakarta : Fakultas Teknik, Universitas Negeri Yogyakarta.Fernando M. 2013. Membuat Aplikasi Android Augmented Reality Menggunakan Vuforia SDK dan Unity. Manado : Fakultas Teknik, Universitas Sam Ratulangi.

Fino ,Y.K. (2015). Ini Alasan Indonesia Jadi Sasaran Ponsel Murah Android One. (http://inet.detik.com/read/2015/02/04/171611/ 2823681/317/ini-alasan-indonesia-jadisasaran-ponsel-murah-android-one) . Diakses 10 Mei 2016.

Kustandi,Cecep (2015). Prosedur Pengembangan Media (cecepkustandi.com/upload/prosedurpengembangan-media), diakses 2 juni 2016.
Purnomo, Windhu. (2006). Uji t Sampel Berpasangan. Handout MK Statistik Parametrik. Surabaya.

Septi Elvrilla. (2011). Augmented Reality Panduan Belajar Sholat Berdasarkan Buku Teks Belajar Sholat Menggunakan Android. Jurnal Teknik Informatika. Universitas Gunadarma.

Siti, Z., Susriyati, M., Lia, Y., \& Darsono, S. (2014). IPA Kelas VIII Semester 1. Jakarta : Kementerian Pendidikan dan Kebudayaan.

Sugiyono. (2011). Metode Penelitian Kuantitatif, Kualitatif, dan $R \& D$. Bandung: Alfabeta. 